\title{
Atypical central neurocytoma with aggressive features in a child
}

\author{
Scott Sun, ${ }^{1}$ Denise M Malicki, ${ }^{2}$ Michael L Levy, ${ }^{3}$ John Ross Crawford ${ }^{4}$
}

'Dearptment of Neurosciences, University of California San Diego, San Diego, California, USA

${ }^{2}$ Pathology, Rady Children's Hospital University of California San Diego, San Diego,

California, USA

${ }^{3}$ Neurosurgery, University of California San Diego, San Diego, California, USA

${ }^{4}$ Neurosciences and Pediatrics, University of California San Diego, San Diego, California, USA

\section{Correspondence to \\ Dr John Ross Crawford;} jrcrawford@ucsd.edu

Accepted 22 May 2020

\section{DESCRIPTION}

A 12-year-old girl presented with 3 months of headaches, blurred vision and progressive vomiting. Neurological examination revealed bilateral papilloedema and mild difficulties with tandem gait. MRI demonstrated a $4 \mathrm{~cm}$ mass within the right lateral ventricle that showed reduced diffusivity on diffusion-weighted sequences, and heterogeneous enhancement (figure 1). Magnetic resonance spectroscopy showed an elevated choline to creatinine ratio. The patient underwent gross total resection where neuropathology revealed a moderately cellular proliferation of monotonous polygonal cells with generally round nuclei, 'salt and pepper' chromatin and a modest amount of lightly eosinophilic cytoplasm and two mitotic figures per high powered field consistent with a diagnosis of atypical neurocytoma (figure 2). A DNA-based next generation sequencing panel consisting of 397 cancerrelated genes performed on paraffin-embedded formalin fixed tumour demonstrated variants of unknown significance in seven genes (DICER1, DOT1L, GATA6, NKX2-1, NOTCH2, PDGRFA, TNFAIP3).

Postoperatively, the patient was found to have left-side haemiplegia that slowly improved. A follow-up MRI performed 1-year postsurgery showed concern for progressive disease that was confirmed on additional follow-up MRI 2 years

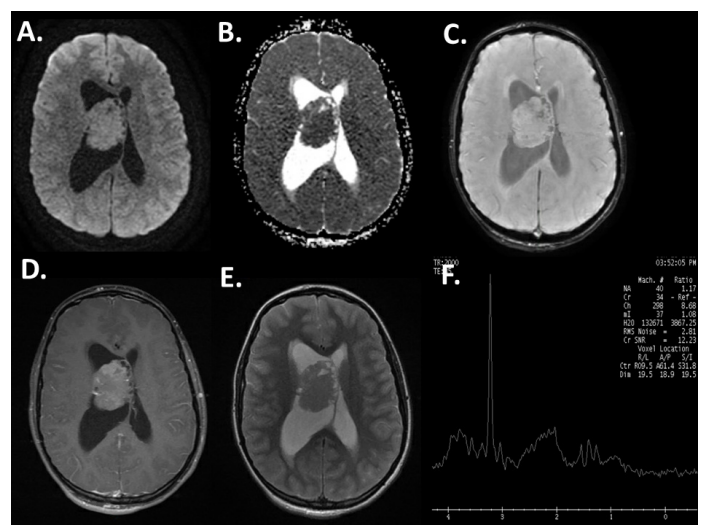

Check for updates

(C) BMJ Publishing Group Limited 2020. No commercial re-use. See rights and permissions. Published by BMJ.

To cite: Sun S, Malicki DM, Levy ML, et al. BMJ Case Rep 2020;13:e236262. doi:10.1136/bcr-2020236262
Figure 1 MRI reveals a ventricular tumour with reduced diffusivity on diffusion-weighted imaging (DWI) and apparent diffusion coefficient (ADC) sequences $(A, B)$ and punctate areas of mineralisation on susceptibility-weighted images (C). The tumour showed avid enhancement on post-T1 gadolinium weighted sequences (D) with associated hydrocephalus (E). Magnetic resonance spectroscopy showed elevation of choline to creatinine ratio consistent with a higher-grade malignancy (F).

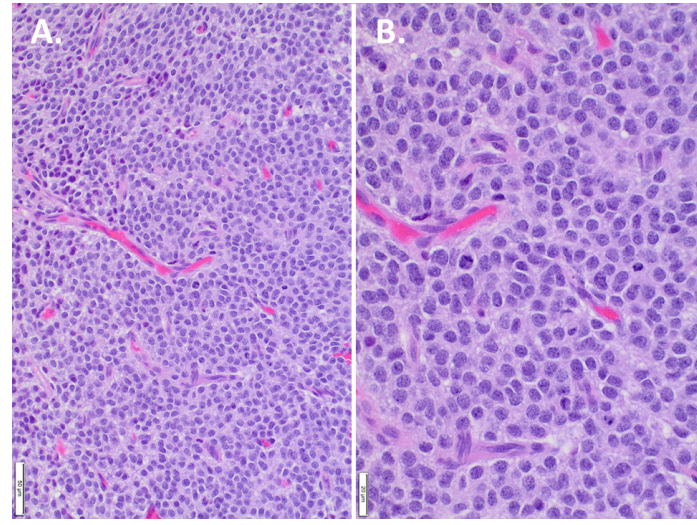

Figure 2 H\&E-stained section of initial tumour at $200 x$ (A) and $400 \times$ (B) magnification demonstrates revealed a moderately cellular proliferation of monotonous polygonal cells with generally round nuclei, 'salt and pepper' chromatin and a modest amount of lightly eosinophilic cytoplasm and two mitotic figures per high powered field consistent with a diagnosis of atypical neurocytoma.

\section{Learning points}

- Central neurocytoma is an extremely rare paediatric tumour with both intraventricular and extraventricular presentations.

- Central neurocytoma is commonly associated with a favourable prognosis; however, atypical features including elevated mitotic index may be associated with worsened survival and require adjuvant therapy following surgery.

- The molecular features of central neurocytoma have not been fully elucidated highlighting the complexity of this rare tumour.

postsurgery, prompting near total resection of the mass. The neuropathology revealed a similar mitotic index as the original tumour and similar histological features. Given the rapid recurrence of tumour the patient underwent focal proton radiation therapy $(5400 \mathrm{cGE}$ whole ventricular with a boost to the tumour bed totalling 5940cGE) following the second resection and has remained in remission for 5 years.

Central neurocytoma is an extremely rare paediatric brain tumour classified by WHO classification as a grade 2 neuronal or mixed neuronal-glial tumour commonly located near the foramen of Monro and lateral ventricles. ${ }^{12}$ In general, neurocytoma is associated with a favourable prognosis 
in cases of gross total resection; however, adjuvant therapy to include chemotherapy or radiation therapy may be required in cases of recurrence or progression. Central neurocytoma with a MIB-1 of greater than 2\%-4\% has been associated with poorer outcome. ${ }^{34}$ Extraventricular locations may occur in children and are generally associated with younger age, seizures at presentation and worsened overall survival. ${ }^{4}$ The molecular understanding of central neurocytoma is less understood than other childhood central nervous system tumours. In summary, central neurocytoma is a rare paediatric brain tumour with ill-defined molecular genetics and may exhibit more aggressive features that require adjuvant therapy following surgery.

Contributors SS was responsible for the design and creation of the case report and approves of its contents. DMM was responsible for the design and creation of the case report and approves of its contents. MLL was responsible for the design and creation of the case report and approves of its contents. JRC was responsible for the design and creation of the case report and approves of its contents.
Funding The authors have not declared a specific grant for this research from any funding agency in the public, commercial or not-for-profit sectors.

Competing interests None declared.

Patient consent for publication Parental/guardian consent obtained.

Provenance and peer review Not commissioned; externally peer reviewed.

\section{REFERENCES}

1 Phi JH, Kim DG. Rare pediatric central neurocytomas. Neurosurg Clin N Am 2015;26:105-8.

2 Bonney PA, Boettcher LB, Krysiak RS, et al. Histology and molecular aspects of central neurocytoma. Neurosurg Clin N Am 2015;26:21-9

3 Imber BS, Braunstein SE, Wu FY, et al. Clinical outcome and prognostic factors for central neurocytoma: twenty year institutional experience. J Neurooncol 2016:126:193-200

4 Zacharoulis S, Morales La Madrid A, Bandopadhayay P, et al. Central versus Extraventricular neurocytoma in children: a clinicopathologic comparison and review of the literature. J Pediatr Hematol Oncol 2016;38:479-85.

Copyright 2020 BMJ Publishing Group. All rights reserved. For permission to reuse any of this content visit https://www.bmj.com/company/products-services/rights-and-licensing/permissions/

BMJ Case Report Fellows may re-use this article for personal use and teaching without any further permission.

Become a Fellow of BMJ Case Reports today and you can:

- Submit as many cases as you like

- Enjoy fast sympathetic peer review and rapid publication of accepted articles

- Access all the published articles

Re-use any of the published material for personal use and teaching without further permission

Customer Service

If you have any further queries about your subscription, please contact our customer services team on +44 (0) 2071111105 or via email at support@bmj.com.

Visit casereports.bmj.com for more articles like this and to become a Fellow 